\title{
A Quarter Century of Structural Unity in the Apostolic Faith Mission of South Africa: A Socio Historical Analysis
}

Mookgo Solomon Kgatle

https://orcid.org/0000-0002-9556-6597

University of South Africa

kgatls@unisa.ac.za

\section{Abstract}

The Apostolic Faith Mission (AFM) of South Africa is one of the largest Pentecostal churches in Africa, with other denominational Pentecostal churches like the Full Gospel and the Assemblies of God. Since its inception in 1908, the AFM of South Africa has been divided into four main sections, namely: black, white, mixed race and Indian, for about 88 years. The church followed the divisions under apartheid in South Africa that divided people according to race, colour and ethnicity, with white people at the forefront of that division. It was only in 1996 that the AFM of South Africa decided to unite under one umbrella, with one constitution governing the structures and the members of the church. The 25 years of unity within the AFM of South Africa call for an evaluation of both the successes and the failures of this unity. Through a socio-historical analysis, it will be possible to identify the achievements of this unity on the one hand, and the loopholes on the other. The paper will show that the identified loopholes are detrimental to the unity of the church and its future. Therefore, in order to experience true unity, the church should address the challenges that compromise this unity by returning to the biblical basis of unity, dealing with structural impediments and encouraging multicultural fellowships. When the above is done, not only will the church experience true unity, but also maintain its growth that the church has experienced over the years of its existence.

Keywords: Apostolic Faith Mission; unity; socio-historical analysis; non-geographic regions; racism

\section{UNISA $\cong$}




\section{Introduction}

The Apostolic Faith Mission (hereafter AFM) of South Africa was started in 1908 and is the largest Pentecostal church in South Africa, alongside other classical Pentecostal denominations like the Assemblies of God and the Full Gospel. The divisions that existed for years in the AFM of South Africa have been well studied by historians inside and outside the church. Similarly, there are various studies indicating that the AFM of South Africa moved towards unity in 1996 (see Anderson 2004, 109; Lapoorta 1996; Melton and Baumann 2010, 162; Paul 2009, 54). Most of these studies acknowledge that it was the black section of the AFM that pushed for unity, more than their white counterpart did (Hunter and Robeck 2009, 273). There are also black personalities that supported unity amidst racial segregation in South Africa, like Frank Chikane, who is acknowledged worldwide. The contribution of this paper is an evaluation of the unity of the AFM in the last 25 years in order to identify the achievements and loopholes of this unity. In order to achieve this, the paper uses socio-historical analysis to evaluate the theoretical framework of unity discourse. A socio-historical analysis shall help in highlighting the achievements of the unity of the AFM, but will at the same time illustrate the failures of the same unity. The aim and objectives of this study are to find ways in which the AFM can deal with the loopholes in order to experience true unity. True unity, in this paper, is separated from structural unity, and defined in terms of a Christian, confessional and biblical meaning of unity. To achieve this, I will introduce the unity of the AFM; highlighting the achievements and loopholes with the aim of finding ways of addressing them.

\section{A Socio-historical Analysis of Church History}

A socio-historical analysis is a method used to study church history by looking at its social aspects. Slade $(2020,7)$ explains that socio-historical analysis is "a research methodology that answers questions about religion or develops explanatory models derived from, in part, a particular focus on the social and historical circumstances surrounding religious belief and practice." In other words, it is the ability to juxtapose the history of a specific church, doctrines, and beliefs with social and cultural practices. Consequently, church history is not only studied in historiography, but its meaning is derived through the lens of social and cultural aspects (see Slade 2020, 7). In this paper, a socio-historical analysis shall assist in the study of the AFM of South Africa over the last 25 years. Through a socio-historical analysis, unity is studied by paying attention to the unity of its people on the ground, as opposed to only focusing on structural unity. This shall be achieved by highlighting the loopholes in the unity of the AFM in the last 25 years, and proposing ways in which this unity shall include the people on the ground.

\section{The Unity of the AFM of South Africa}

The AFM of South Africa was a divided church, according to black, white, mixed race and Indian sections, for about 88 years. The process of unity started first with the three groups: black, mixed race and Indian; coming together to form what is called the 
composite division in September 1990 (Kgatle 2017, 7). Anderson (2000, 99; cf. Matika 2004, 70) explains in his book that because the white members of the AFM were very reluctant to unite, it was agreed in a meeting in Shepstone, Port Elizabeth, South Africa that the three black sections (i.e., black, mixed race and Indian) should continue with unity. In addition, negotiations to bring all sections together stretched from 1981 to 1986; hence, the three sections became impatient and united on their own (Paul 2006, 80). In this period, the divisions of the AFM were reduced from four to two, that is, the composite group and the white divisions. This arrangement was caused by the refusal of the white section to unite with other sections to form one unit. In the words of Horn (1991, 1), in 1991 two sets of constitutions were allowed to govern both the composite division and the white division separately. Lapoorta $(1996,115)$ remarks that although the divisions still existed in this period, the difference is that white control was minimised, as black people had their own constitution. However, Richardson $(2013,30)$ points out that the white section still had control over the major policies that governed the AFM of South Africa. In addition, white pastors were appointed to oversee the work of black pastors, according to Anderson $(2005,51)$. This means that the two divisions of the AFM did not solve the problem of racial segregation and white supremacy by the minority white members of the church. Although some of the control was minimised, the white people still led the major decision-making bodies of the church that undermined black contribution.

In light of the challenges highlighted above, the two presidents of both divisions, Reverend Frank Chikane of the composite division, and Isak Burger of the white division, led talks towards the structural unity of the church. During this time, the white division was still reluctant, as it took them until 1995 to fully adopt the new constitution that would govern the church, whereas the composite division had already adopted it in 1994 (Paul 2006, 80). The adoption of the constitution led to a faster move towards unity by both parties; an important meeting was held on 22 February 1995 to pave the way forward (Burger and Nel 2008, 429). When some of the members in the composite division wanted to give up, Frank Chikane motivated them never to lose hope, citing that one day God would answer their prayers (Kgatle 2017, 8; cf. Kgatle 2018, 5). On the other hand, most white members harboured fears to continue with unity, citing that the black majority would dominate over them. Some were actually in fear of losing their properties to the church because of the proposed unity. Therefore, it also took Dr Isak Burger to motivate them and explain clearly the process and benefits of unity in the AFM (Nel 2012). Thus, both Chikane and Burger were instrumental in convincing their own people to move towards structural unity in the AFM. The two were also instrumental in giving up power, because the unified AFM meant that only one president could lead the church. However, their appreciation should not be at the expense of other role players like Apostle Ronny Naidoo, who was influential among Indians for his involvement in the training of pastors and the planting of many local churches (Clark 2007, 42). Naidoo also helped in convincing his own Indian people to agree to unite with other sections to become one organisation. 
In 1996, the AFM of South Africa moved towards unity, marking an end of racial divisions that had existed in the church for almost 90 years since its inception. This was a long walk to unity, according to Erasmus $(1996,128)$, as it took about 22 years since negotiations started in 1974 until finalisation in 1996. Both the composite and the white divisions were structurally brought together to function as one unit (Chandomba 2007, 40). Dr Isak Burger became the president of the united AFM of South Africa, with Reverend Frank Chikane as his deputy. According to Anderson $(2000,100)$, the church moved towards a common constitution and the executive that governed various departments of the church. Kgatle $(2017,8)$ adds: "It meant that the church had one constitution, one legal persona, one Workers' Council, one Executive Council and open membership." Furthermore, the leadership structures of the AFM are represented by almost all ethnic groups in the church, unlike in the past where they were dominated by white leaders (Richardson 2013, 31). It must be explained here that although various sections of the AFM had their own structures before unity, in most cases white missionaries were delegated to oversee the black work. This kind of arrangement ended with the unity of the church in 1996. Other changes that came with unity included the governance by the national structure, called the National Leadership Forum (NLF), which is comprised of the regional leaders from various regions, whereas the national office bearers of the church (doing the normal day-to-day running of the church), comprised of the president, deputy, general secretary and treasurer. On the ground there are various departments governing children's ministry, the youth and women (Clark 2007, 50). In recent times, there is also a men's forum governing the men of the church in various local assemblies. All these structures do meet in an annual conference (to celebrate their existence) during women, youth, and men's conferences.

\section{Highlights of Unity in the AFM of South Africa}

One of the highlights of unity in the AFM of South Africa, is that it destroyed a long history of racial segregation, oppression and white supremacy that oppressed black people not only in the church, but also in society (Mathole 2006, 252). Whereas in the past the black members of the church were called adherents, after 1996 they were fully recognised as members of the church (Anderson 2001). Black leaders that were only recognised as brothers and sisters, elders and deacons, were accepted as full assembly leaders or pastors in the AFM of South Africa. Clark $(2005,143)$ adds: "The new unity constitution of the AFM (adopted in 1996) does not allow for any racial distinctions to be made in terms of membership, office or ministry in the church." Thus, bringing in the body of Christ a spirit of renewal and reconciliation among people of different colour and ethnic groups. Hence, the AFM received respect from both political and religious organisations in South Africa. This made the AFM to be respected and received by organisations such as the South African Council of Churches (SACC) and the World Council of Churches (WCC) (2006). Chikane, quoted in Andrew (2005, 83), says:

[The] Unity act of April 1996 has given the AFM a new face in South Africa to show in our broken society, a miracle of God's healing and restoration. The AFMSA could now 
spread the Gospel in partnership and share their resources. They could now also share their gifts with other churches, and this sharing has ecumenical implications.

Furthermore, the AFM now has a voice at an international level, as many of the black leaders are given an opportunity to make presentations at international conferences.

Another important highlight is the use of language as a medium of communication in the local assemblies and other formal structures. Whereas local assemblies are allowed to express themselves in their indigenous languages, in general meetings a common language that everybody can understand is used-in this case it is English. The issue of language, according to Chandomba $(2007,41)$, is a key change bringing down the Afrikaans dominance in the AFM of South Africa. However, according to Nel (2012, 39) the indigenous languages are still important as they help individuals to retain their cultural identity. Bringing people together from various cultural backgrounds should not be at the expense of them losing their own identity in light of their mother tongue. Therefore, it is clear that the problem is not language, but the dominance of one language over other languages. In this context, it was the dominance of Afrikaans over African languages during racial segregation in the AFM and the South African society. Black South Africans should take caution that the use of English does not dominate them in the same way that Afrikaans has done in the past. While unity is important to ensure that black people do not lose their identity, there is also a need for the promotion of African languages from the Early Childhood Development phase (ECD as it is known in South Africa). Actually, even in some of the children's ministry classes in local assemblies, children should be taught in their mother tongue.

The last highlight of the unity in the AFM of South Africa is the autonomy of local assemblies. In the past, white missionaries supervised most black assemblies, but with unity these assemblies are now able to have their own local governing body, property, and local assembly pastor (Watt 2001, 73). Power has been decentralised in the AFM, allowing local assemblies to draft and adopt their own local policies. The local assembly is allowed to make final decisions on its own, have assembly leaders and a local vision in the context of the community within which it is operating (Kgatle 2017,2). It is in local assemblies where the AFM is able to grow, as the slogan goes "wherever you are, there is an AFM." Thus, by empowering the local assemblies, the vision of planting and growing assemblies in every city of South Africa has become a reality. According to Kgatle $(2017,2)$ :

This decision by the united AFM of South Africa has caused the church to grow in terms of numbers and financial income of assemblies because unlike in the past, to a certain extent, the church no longer monopolises leadership but allows autonomy.

The only disadvantage here is that those who still want to control the church and its property are still able to do so, given the autonomy of the local assembly. They can convince the local governing body to draft and adopt local policies in their favour and 
be able to maintain control over the church. This brings us to the next section on loopholes in the unity of the AFM in South Africa.

\section{Some Loopholes in the Unity of the AFM of South Africa}

Though the unity of the AFM has achieved a lot for the church over the last 25 years, this paper acknowledges some challenges through a socio-historical analysis. Clark $(2007,50)$ says that the unity in the AFM was more of an acceptance of a democratic reality in South Africa since 1996, than an expression of a Christian confession or biblical convictions by white membership. The white division of the church became ready to move towards unity, following the democratic elections in 1994. It can be concluded that unity in the AFM was more influenced by the political climate of the 1994 democratic elections, forcing the church into a structural unity but not a confessional or a Christian unity in light of the scriptures. It also implies that church unity has been achieved on a constitutional and institutional basis, but on the ground, people are not as united. The constitution exists in theory but in local assemblies, white people are still allowed to do their own thing; and the same goes for black people. Thus, the outsiders celebrate this kind of unity as a great achievement of the church, but the insiders still know that they are not as united as they are perceived to be. It is more of a forced unity, where people agree to unite on paper but cannot do so in their actions, which is a sign of pretence.

The main challenge to the unity of the AFM is the concept of non-geographical regions, that were constitutionally allowed to operate since 2000. Many of the big urban churches of the AFM felt uncomfortable in submitting to the geographical regions of the church. Some of them withdrew their financial contributions to these geographical regions, arguing that they did not administrate the finances according to their ministerial needs. Most of these churches were allowed (according to the constitution that was adopted in 2000) to group themselves into non-geographical regions or networks (as they are known), of which many are white Afrikaans networks. These networks, according to Clark (2007, 52), are:

The re-establishment of racial divisions within the church, but now on an ostensibly voluntary basis. Many medium and large local churches simply abandoned the challenges of regional racial unity in favour of joining networks consisting primarily of White Afrikaans churches.

Mofokeng $(2018,108)$ concurs:

Since the adoption of the new constitution in 2000, it became the AFM's principle of unity in diversity. However, the adoption of this principle arose from the need of some in the white sector of the united AFM to create safe space for preserving Afrikaner culture, language and control.

This is somehow creating two centres of power within the same church, where churches that are affluent and mainly white belong to one grouping, and the churches that are 
poor and mainly black belong to another grouping. Some black pastors affiliate to nongeographic regions, but do so to receive financial support from their white Afrikaner pastors without any policy or ministerial contribution to such regions (Kgatle 2019, 2). Therefore, the concept of non-geographic regions does not unite people but encourages some form of classism and elitism within the church that is supposed to be at the forefront in preaching and enhancing unity. The existence of non-geographic regions means that more and more pastors (whose assemblies cannot cater for them), will be pulled out of their geographic regions to join the networks-which must be seen as a new form of divisiveness.

Another challenge facing the AFM of South Africa, is that - even after unity-most assemblies are still categorised as either a white assembly or a black assembly. During my seminary days between 2006 and 2009, we still had the Afrikaans service and the English service in one local assembly at the Auckland Park Theological Seminary, Johannesburg, South Africa. The question is: Why could we not have one unified and strong service that will become multi-cultural and would cater for everyone in that context? Why was there a need to separate people into Afrikaans and English? Most of us who attended the English service were not even English, but we attended it because we could not understand Afrikaans. So many assemblies have maintained this practice of having two services on Sundays to cater for the Afrikaans-speaking members and the English-speaking ones. Other than the examples given above, in other assemblies there are either predominantly black or predominantly white members. Few assemblies are able to have different cultures and races in one place. On the contrary, when more black people join the predominantly white churches, the white people leave the church. Pastor Dennis Erasmus and Antoinette Erasmus of AFM Impact Christian Centre in Midrand shared a story of how-when they started to allow other cultures into their former predominantly Afrikaans assembly — most Afrikaners left the church to join Afrikaansonly assemblies.

Another interesting scenario in South Africa is a growing trend of the AFM churches that can be classified as Shona (the official language for most Zimbabweans) churches. This is because of the great presence of Zimbabweans in the AFM of South Africa, specifically in the Gauteng province. In order to maintain their culture and language, there are specific churches that retain their Zimbabwean identity in their liturgy. Such churches have a great following by the Zimbabwean nationals, because the singing and preaching is done in Shona. However, groupings such as Shona churches are further dividing people in terms of language and culture. Churches like these are unable to reach out to the local people, as they only use the language of their country of origin. Thus, even if South Africans were interested in joining such churches, they cannot do so because they will face the challenge of language in worship and sermons. The sustainability of such churches is also a greater challenge, because as many Zimbabweans relocate back to their country, it means membership will decrease. Therefore, there is a greater need for local churches and immigrant churches of the AFM to move towards true unity for sustainability. 


\section{Signs of Disunity in the Theological Education of the AFM of South Africa}

The AFM of South Africa has always believed in the formal training of pastors for the work of ministry, even during racial segregation. According to Clark $(2005,158)$, "the general acceptability of formal theological education has also led to a large number of theologians progressing to doctoral level in their studies, making the AFM one of the highest qualified (per capita) Pentecostal denominations in the world." This paper does not wish to go into detail about the theological education history in the AFM, but wishes to point out that with the attainment of unity in 1996, the church leadership wanted all theological colleges of the AFM to be under one umbrella. According to Nel (2014, 123) "it was decided in principle that there would be only one Theological institute for the AFM, with satellites linked to it." Thus, the NLF mandated all the departments and theological institutions that were previously organised according to different races to unite (Nel 2014, 123). This move was motivated by the fact that the theological colleges in the AFM were still organised in terms of race: the Auckland Park Theological Seminary in Johannesburg serving white people (Nel 2014, 123); and the AFM of South Africa Theological Institute and Sarepta Theological College serving black people. All the above-mentioned colleges in the AFM were independent of each other, with each having its legal status.

Nel $(2014,124)$ continues to say that "unification on all levels except theological training had been achieved by the time that the AFM adopted a new Constitution for the one united AFM at the Workers' Council of 1999." Unfortunately, the efforts to unite the theological colleges of the AFM were unsuccessful; however, most of them were allowed to continue with business while moving towards unity (Nel 2014, 124). The main challenge to unite came from the Auckland Park Theological Seminary, hence according to Nel and Van Rensburg $(2016,6)$ :

After the three institutions had signed the Memorandum of Agreement, ATS withdrew from the unity process on 19 May 2008 and decided to continue independently from the Pentecostal Theological Seminary as indicated in a letter sent on 10 October 2008 by Prof Jan Hattingh to all ATS students.

The reasons given why the Auckland Park Theological Seminary seceded, were the lack of transparency in the negotiations and, therefore, perceiving their incorporation into the new college as a forced move (Nel and Van Rensburg 2016, 6). The Auckland Park Theological Seminary was willing to negotiate and follow the mandate by the National Leadership Forum in 2005, in the way they understood the mandate. However, the National Leadership Forum instituted a court case which led to a series of court battles between the AFM of South Africa and the Auckland Park Theological Seminary. The main battle between the two is the ownership of the Article 21 Company, which was previously owned by the Auckland Park Theological Seminary, but the church had claimed it when the seminary signed an agreement for unification. However, the Auckland Park Theological Seminary argued that it made an agreement to begin with the unification process, but not necessarily the incorporation into the new theological 
college. Thus, when they seceded from the unification process, they demanded to receive the Article 21 Company ownership (Nel and Van Rensburg 2016, 7). After a series of legal battles, the court finally pronounced in 2013 that the company belonged to the AFM of South Africa. However, Auckland Park Theological Seminary refused to vacate the premises in Auckland Park, Johannesburg. The latest is that the Auckland Park Theological Seminary is still using the premises and have registered with the Department of Higher Education in South Africa (DHET).

\section{Moving towards True Unity in the AFM of South Africa}

I am of the view that the structural unity of the AFM does not necessarily translate to the true unity of the church in light of the scriptures. Thus, in order for the church to experience true unity, there is a need to return to the biblical basis of unity that Andrew $(2005,134)$ describes as a unity of the body of Christ, where all members of the AFM of South Africa (regardless of race) are part of that body. Andrew $(2005,135)$ states: "The unity of the believers exists in the fact that those who are part of Christ are united in His body." Thus, all the members of the AFM of South Africa are brothers and sisters because they serve the same God and He is the father to all of them. This oneness of the body does not diminish the diversity of cultures that exists in the AFM, but rather encourages unity in diversity (Andrew 2005, 136). Matikiti $(2017,138)$ adds that the inclusion of culture is relevant for unity, given the many diverse cultures in Africa. If indeed the AFM of South Africa is the church of the Holy Spirit, the same Spirit should be able to unify all people in their diversity (Matikiti 2017, 138). Hence, Richardson $(2013,27)$ opines that the divisions of the church that had existed for a long time, were actually the misrepresentation of the gospel. Watt $(2001,82)$ concurs: "Apartheid was therefore a denial of the gospel and a refusal to accept the implications of the unity of the Spirit — a heresy, however it was 'dressed up' and theologically rationalised."

The gospel is the message of unity that the psalmist David spoke of, emphasising how wonderful it is for humanity to dwell together in unity, likening this type of unity to the oil that flows and the blessing that the Lord commands upon his people (Psalm 133). This means that until the people of God agree in unity, the organisation will not flow and it will rob itself of the blessing of God. Hence, Paul encouraged the church to always keep the unity of the Spirit in conjunction with the peace that comes from such unity (Ephesians 4:13). Elsewhere, he taught that the body is one although it has various members; whether Zulus, Sotho's, Afrikaner or Xhosa, we remain one body. In the gospel of John, the prayer of Jesus is very clear; he prays for his disciples to be one as $\mathrm{He}$ and the Father are one- thus, encouraging unity of the church from the unity that exists in trinity. Jesus is very clear that it is only when the disciples keep the oneness that the world will finally approve of Him (John 17:23). The AFM of South Africa needs to preach this gospel among its membership in order to experience true unity in all its structures.

The move towards true unity should not only be addressed from a biblical perspective, but also from the structural challenges as highlighted in the previous section. From the 
understanding of the meaning of unity in the Bible, there is a need to move to unity in structural practices (Watt 2001, 83). According to Lapoorta (1996, 253), true unity happens by changing structures and formulating laws that will reverse the challenges of the past. The challenge of non-geographic regions needs to be addressed, as it creates two systems in the church and perpetuates division that existed prior to 1996. If the church has achieved unity, there is no need to still have networks that exist for rebelling against proper regions that exist in specific areas. As stated previously, some churches dissociated themselves from local regions, to go and organise themselves into networks that speak the same language, therefore reversing the very unity achieved in 1996. Instead of running away from the local regions, local assemblies and pastors should be encouraged to stay and solve any challenge they face in the region. Local pastors should be free to associate with whomever they wish, but not at the expense of regional structures that are fostering unity in the church.

Lastly, the coming together of people in fellowship with one another, and in full participation of all members of the church, can express true unity. Resane $(2018,7)$ says: "Participation refers to partnership or involvement: engagement in something for a common good, when koinonia demonstrates togetherness and unity for the common purpose." Köstenberger $(2017,445)$ adds that the faith that is able to bring people of different cultures together and advance fellowship, is the centre of true unity in the church. Ntlha $(2007,43)$ reiterates that the unity of the church is complete when those who are born again are able to fellowship with one another. However, in the fellowship of the saints there is also a need for social cohesion, which also advances the prospects of a true unity (Molobi 2014, 3). The role of the Holy Spirit is the empowerment of individuals to bring them into fellowship, participation and social cohesion with others (Watt 2001, 83). The Holy Spirit is the unifier, as He is able to mediate between people of different backgrounds, languages and races. Therefore, true unity shall be experienced in the AFM of South Africa, by not only obeying the constitution of the church, but also obeying the voice and guidance of the Holy Spirit.

\section{Conclusion}

Many scholars (as both insiders and outsiders) have written on the unity of the AFM of South Africa that the church achieved in 1996. They have demonstrated that the church, which used to be divided according to race, is now united under one umbrella and one constitution governing the structures and the members. Indeed, these scholars agree that this unity brought renewal and reconciliation for not only the church, but also for the whole society in the context of the racial divisions that existed in South Africa for many years. However, a socio-historical analysis of this unity illustrates the challenges that persist - even post unity. One of these challenges is the non-geographic regions of the AFM that pose a threat to the unity of the church. The paper also highlighted the challenges that persist with the theological education of the AFM of South Africa, whereby one college has refused to unite with others. The proposal in this paper is that the AFM of South Africa should reconsider the concept of non-geographic regions, as 
most of them are a reversal of church unity. Some of the non-geographic regions are actually creating two centres of power in the church, and are still serving the white Afrikaans minority members of the church. Addressing the problem of non-geographic regions and other challenges will ensure that the AFM of South Africa realises true unity that it is sustainable, even for the coming generations. The church should have one united theological college that will be responsible for the training of its pastors, in order to avoid future division within its theological training.

\section{References}

Anderson, A. H. 2000. Zion and Pentecost: The Spirituality and Experience of Pentecostal and Zionist/Apostolic Churches in South Africa. Pretoria: University of South Africa Press.

Anderson, A. H. 2001. "Pentecostals and Apartheid in South Africa during Ninety Years 19081998." Cyberjournal for Pentecostal-charismatic Research.

http://www.pctii.org/cyberj/cyberj9/anderson.html.

Anderson, A. H. 2004. An Introduction to Pentecostalism: Global Charismatic Christianity. Cambridge: Cambridge University Press.

Anderson, A. H. 2005. "The Dubious Legacy of Charles Parham: Racism and Cultural Insensitivities among Pentecostals." Pneuma 27 (1): 51-64. https://doi.org/10.1163/157007405774270392.

Andrew, D. N. 2005. "From Vision to Structure: Assessing the Apostolic Faith Mission of South Africa in the Light of the One, Holy, Catholic and Apostolic Church." PhD thesis. Bellville: University of the Western Cape.

Burger, I., M. Nel. 2008. The Fire Falls in Africa: A History of the Apostolic Faith Mission in South Africa: A Centennial Edition 1908-2008. Vereeniging: Christian Art Publishers.

Chandomba, L. 2007. The History of the Apostolic Faith Mission and other Pentecostal Mission in South Africa. Milton Keynes: Authorhouse.

Clark, M. 2005. "Two Contrasting Models of Missions in South Africa: The Apostolic Faith Mission and the Assemblies of God.” Asian Journal of Pentecostal Studies 8 (1): 143-161.

Clark, M. 2007. "Contemporary Pentecostal Leadership: The Apostolic Faith Mission of South Africa as a Case Study." Asian Journal of Pentecostal Studies 10 (1): 42-61.

Erasmus, L. J. 1996. "Theological Education in the Apostolic Faith Mission of South Africa." $\mathrm{PhD}$ thesis. Pretoria: University of South Africa.

Horn, N. 1991. "Crossing Racial Borders in Southern Africa: A Lesson from History." Cyberjournal for Pentecostal-charismatic Research. http://www.pctii.org.cyberj/index.html. 
Hunter, H. D., C. M. Robeck (Eds). 2009. The Azusa Street Revival and its Legacy. Eugene, Oregon: Wipf and Stock Publishers.

Kgatle, M. S. 2017. "A Socio-historical Analysis of the Sections in the Apostolic Faith Mission of South Africa from 1908 to the Present." Verbum et Ecclesia 38 (1): 1-10. https://doi.org/10.4102/ve.v38i1.1668.

Kgatle, M. S. 2018. "Servant Leadership: The Style of Frank Chikane from Early Life to the Presidency of Thabo Mbeki.” Studia Historiae Ecclesiasticae 44 (2): 1-17. https://doi.org/10.25159/2412-4265/2033.

Kgatle, M. S. 2019. "Gender Dimensions in Pentecostal Leadership: The Apostolic Faith Mission of South Africa as a Case Study." Verbum et Ecclesia 40 (1): 1-7. https://doi.org/10.4102/ve.v40i1.1980.

Köstenberger, A. J. Commentary on 1-2 Timothy and Titus. Nashville, Tennessee: B \& H Publishing Group.

Lapoorta, J. J. 1996. Unity or Division? The Unity Struggles of the Black Churches within the Apostolic Faith Mission of South Africa. Kuils River: Japie LaPoorta.

Mathole, E. M. K. 2006. "The Christian Witness in the Context of Poverty with Special Reference to the South African Charismatic Evangelicals." PhD thesis. Pretoria: University of Pretoria.

Matika, B. M. 2004. Religion and the Advent of Democracy in South Africa. Houston: Texas Woman's University.

Matikiti, R. 2017. "Moratorium to Preserve Cultures: A Challenge to the Apostolic Faith Mission Church in Zimbabwe?" Studia Historiae Ecclesiasticae 43 (1): 138-148. https://doi.org/10.25159/2412-4265/1900.

Melton, J. G., M. Baumann (Eds). 2010. Religions of the World: A Comprehensive Encyclopedia of Beliefs and Practices, [6 volumes]. Santa Barbara, California: Abc-Clio.

Mofokeng, T. R. 2018. "Throwing the Baby out with the Bathwater: Cultural Reorientation of Black Pentecostalism in the Apostolic Faith Mission of South Africa, 1940-1975.” PhD thesis. Pretoria: University of South Africa.

Molobi, V. 2014. "Living in the Townships: An Appraisal of Pentecostal Social Ministry in Tshwane.” HTS Theological Studies 70 (3): 1-9. https://doi.org/10.4102/hts.v70i3.2791.

Nel, M. 2012. "The Process of Unification of the AFM of SA." Studia Historiae Ecclesiasticae 32 (2): 121-141.

Nel, M. 2014. "A Hundred Years of Theological Training in the Apostolic Faith Mission of South Africa." Acta Theologica 34 (1): 108-126. 
Nel, M., and F. Janse van Rensburg. 2016. “Integrating Spirituality and Rationality: The Long and Arduous Journey of the Historical Development of Theological Training in the Apostolic Faith Mission of South Africa.” In die Skriflig 50 (2): 1-10.

Ntlha, M. K. S. 2007. "Evangelicals and Ecumenism in South Africa 1960-1990:

Opportunities and Pitfalls.” PhD thesis. Durban: University of KwaZulu-Natal.

Paul, S. A. 2006. Deconstructing a South African Narrative of Oppression. The Influence of Religion in Public Policy: Christianity in South Africa, 1948-2004; Exploring the African Narrative of Ubuntu. Pasadena: Fuller Theological Seminary, School of Theology.

Paul, S. A. 2009. The Ubuntu God: Deconstructing a South African Narrative of Oppression, Vol. 101. Eugene, Oregon: Wipf and Stock Publishers.

Resane, K. T. 2018. "Pentecostals and Apartheid: Has the Wheel Turned around since 1994?" In die Skriflig 52 (1): 1-8. https://doi.org/10.4102/ids.v52i1.2324.

Richardson, L. 2013. What has Pentecostalism to do with Race Relations: A Study of the Apostolic Faith Mission in South Africa. Regent: Regent University.

Slade, D. M. 2020. "What is the Socio-Historical Method in the Study of Religion?" SHERM Journal 2 (1): 1-15. https://doi.org/10.33929/sherm.2020.vol2.no1.01.

Watt, C. P. 2001. "Struggle for the Centre: South African Pentecostal Missiology in Context." PhD thesis. Pretoria: University of South Africa. 